\title{
The influence of the ATO bangles action on personality of military man: post-traumatic development
}

\author{
A. A. Tkachenko \\ Developmental psychology department, Psychology at the Faculty of Taras Shevchenko National University of Kyiv, Ukraine \\ Corresponding author. E-mail: altkachenko2@gmail.com
}

Paper received 19.02.18; Accepted for publication 01.03.18.

\section{http://doi.org/10.31174/SEND-PP2018-162VI66-18}

Abstract. The effect of post-traumatic growth and sense dynamics before, during and after the fighting during the ATO and the return of the military man to peaceful conditions is studied. In general, the positive influence of extreme situations on the development of the veteran personality is revealed. The main problem is related to the sense contradiction in understanding the values of life on the part of those who were in peaceful conditions.

Keywords: post-traumatic growth (PTG), ATO (antiterrorist operation), bangles actions, sense dynamics, and development of personality.

Psychological peculiarities of the ATO (antiterrorist operation) in the east of Ukraine, as outlined in the paper [4], revealed a number of problems due to the contradiction between the real formation of the personality of the participant in the hostilities on the basis of the state of "basal patriotism" (author's term) and the leading motive directed at "protection ", and most of the existing methodological and practical recommendations of psychological work with veterans, based on the instinct of self-preservation and the leading motive aimed as "murder". It is a variety of sense intentions, directed respectively "to life" and "to death" in the context of the time perspective of the individual [2]. Such a difference activates not only various psychic functions and areas of the brain, but also psychological practice and the construction of a life of a person after experiencing critical situations, and therefore requires the use of another, post-classical scientific paradigm for research [3].

Author's psychological practice in combat operations of the ATO suggests that, in critical situations, the effect of post-traumatic growth (PTG) is the main productive benchmark, first described by R. Tedeshi and by L. Calhoun $[5,6]$ as the reverse side of post-traumatic stress disorder, which determines an alternative result to overcome injuries associated with severe life-threatening crises. A detailed description of this phenomenon is presented and the following spheres of human life are proposed, where post-traumatic growth can be manifested: finding new opportunities in life; a sense of the growth of personality; great affinity and recognition from other people; awareness of the value of life in general; growing interest in the spiritual sphere of life.

Experimental research was carried out both in the area of combat operations in the operational rear and directly on the line of collision, and after the return of the soldiers as ordinary veterans and cadets-psychologists of the military institute. Cadets-psychologists, who did not participate in combat operations, were also studied (women was distinguishedseparately). The total experimental sampling was 154 persons and was formed on a voluntary basis. It included the following groups: №1 - operative rear troops in the combat zone that have not yet fought; №2 - servicemen who were directly on the line of contact and took an active part in combat operations; №3 - ordinary veterans in peaceful conditions; №4 - veterans, cadets-psychologists of the military institute; №5 - cadets-psychologists of the military institute who did not participate in military operations; №6 - cadets-psychologists of the military institute (women); №7- control group of civilian psychology students. The research was carried out at the following stages: 1- Preparation for combat operations (gr. №1); 2 - direct fighting (gr. №2); 3 - after returning to peaceful conditions (gr. №3 and gr. №4); 4 - peaceful conditions, not related to the war (gr. gr. №5, №6, №7).

As standardized tools, the following techniques were used: the post-traumatic growth questionnaire (PTGQ) of Tadeshi and Calhoun in the adaptation of M.Sh. MagomedEminova [2]; modified version of Nutten's method of unfinished sentences (in the adaptation of M.Sh. MagomedEminova) [2]; SPSS version 19.0 was used for statistical processing of the results.

On the basis of PTGQ, the following factors were identified: attitude to others (AO), new possibilities (NP), personality (P), spiritual changes (SC), increase in the value of life (VL), and the overall rate of post traumatic growth (PG). Characteristics of the sample and the results of the study are presented in Table 1.

Table 1. Results of research for PTGQ

\begin{tabular}{|c|c|c|c|c|c|c|c|c|c|c|c|c|}
\hline \multirow{2}{*}{$\begin{array}{c}\text { № } \\
\text { gr. }\end{array}$} & Amount of & Average & Spenti in ATO & \multicolumn{7}{|c|}{ Andicators (points) } & \multicolumn{3}{|c|}{ Distribution PG (\%) } \\
\cline { 5 - 14 } & page (years) & (month) & AO & NP & P & SC & VL & PG & High & Middle & Low \\
\hline №1 & 20 & 35,4 & 4,8 & 9,7 & 11,8 & 8,8 & 2,5 & 7.0 & 39,8 & 19 & 38 & 43 \\
\hline №2 & 24 & 33.0 & 4.6 & 17.2 & 11.6 & 11.8 & 6.1 & 11.0 & 57,7 & 50 & 35 & 15 \\
\hline №3 & 25 & 33,6 & 19,5 & 14.9 & 13.5 & 12.0 & 3.5 & 9.6 & 53,5 & 40 & 48 & 12 \\
\hline №4 & 20 & 23,7 & 11,0 & 13,1 & 19,1 & 15,2 & 4,3 & 12,2 & 63,9 & 60 & 40 & 0 \\
\hline №5 & 25 & 21,0 & 0 & 14,0 & 14,5 & 11,2 & 4,8 & 10,1 & 54,6 & 29 & 63 & 8 \\
\hline №6 & 20 & 21,3 & 0 & 15,6 & 15,5 & 13,1 & 5,3 & 9,1 & 58,6 & 38 & 62 & 0 \\
\hline №7 & 20 & 20,4 & 0 & 16,8 & 11,8 & 10,0 & 4,5 & 7,5 & 50,6 & 20 & 50 & 30 \\
\hline
\end{tabular}

For the processing of text materials on the questionnaire of unfinished speeches, the main attention was paid to the semantic dynamics in the context of the expediency of constructing a life-long return from war on the basis of 
newly acquired moral and ethical values. Therefore, first of all, we were interested not in ontological but axiological meanings. For this analysis, we used the idea of semantic modeling by T. A. van Dijk [1], and the following original procedure was used to identify axiological concentrated meanings.

Semantic analysis of texts, which was conducted using the appropriate computer program [8]. The most commonly used words were allocated and distributed according to the Zipf law [7] with the corresponding quantitative characteristic of the frequency of use, as their value in the analyzed text, which allowed to distinguish the corresponding "semantic core" for each group under study. 2) Correlation analysis was conducted on the basis of comparison of "semantic nuclei" of the studied groups in the following way. Initially, a set of identical words in the comparable groups was allocated, which was the "common semantic core"
(CSC), which was taken into account for the determination of the Pearson correlation coefficient $\left(r_{x y}\right)$ and was perceived as the level of intergroup understanding in this way: complete - in the presence of correlation, potential - for $\mathrm{r}_{\mathrm{xy}}$ $=0.60-0.69$; low - at $r_{x y}=0.40-0.59$; absent-at $r_{x y}=0.39$ and below.The remnant of words that were not included in the CSC was a "specific semantic core" (SSC) for each of the groups or stage compared. The results of the intergroup correlation analysis of texts, ranked in accordance with the reduction of $r_{x y}$, are presented in Table 2. 3) The sense analysis was carried out by the experimenter on the basis of CSC and SSC, and provided for the creation of a"common concentrated sense" (CCS) and a "specific concentrated sense" (SCS), respectively, for all comparable groups. The results of semantic and sense analyses according to the studied stages are presented in Table 3.

Table 2. Results of correlation analysis of texts

\begin{tabular}{|c|c|c|c|c|c|c|}
\hline Range & $\begin{array}{c}\text { Compared } \\
\text { groups }\end{array}$ & $\mathrm{r}_{\text {xy }}$ & $\begin{array}{c}\mathrm{R}_{\text {crit }} \\
\text { atp=0.05 }\end{array}$ & $\begin{array}{c}\mathrm{R}_{\text {crit }} \\
\text { atp=0.01 }\end{array}$ & $\begin{array}{c}\text { The presence / absence } \\
\text { of the correlation }\end{array}$ & $\begin{array}{c}\text { The level of } \\
\text { understanding }\end{array}$ \\
\hline 1 & №4 - №2 & 0.77 & 0.39 & 0.50 & yes & full \\
\hline 2 & №2 - №3 & 0.65 & 0.58 & 0.71 & yes & full \\
\hline 3 & №4 - №3 & 0.65 & 0.40 & 0.51 & yes & full \\
\hline 4 & №6- №2 & 0.69 & 0.71 & 0.83 & no & potential \\
\hline 5 & №1-№2 & 0.64 & 0.71 & 0.83 & no & potential \\
\hline 6 & №6 - №3 & 0.63 & 0.67 & 0.8 & no & potential \\
\hline 7 & №6 - №4 & 0.57 & 0.63 & 0.77 & no & low \\
\hline 8 & №5 - №7 & 0.45 & 0.55 & 0.68 & no & low \\
\hline 9 & №4 - №7 & 0.33 & 0.53 & 0.66 & no & absent \\
\hline 10 & №4-№5 & -0.05 & 0.71 & 0.83 & no & absent \\
\hline
\end{tabular}

Table 3. Results of semantic and sense analysis

\begin{tabular}{|c|c|l|}
\hline \multirow{2}{*}{ Stage } & CSC & peace, everything, live, well, be, own, people \\
\cline { 2 - 3 } & CCS & Everything will be fine, my own people live peacefully \\
\hline \multirow{2}{*}{1} & SSC & peace, know, country, own, one, sense, be, think, want, help \\
\cline { 2 - 3 } & SCS & $\begin{array}{l}\text { Everything will be fine, my people live peacefully, they want to know their only country, they think about the sense } \\
\text { of helping it. }\end{array}$ \\
\hline \multirow{2}{*}{2} & SSC & peace, know, country, own, think, war, life, family, finish, return, home \\
\cline { 2 - 4 } & SCS & $\begin{array}{l}\text { Everything will be fine, my people live peacefully, know their country, they are thinking of ending the war to return } \\
\text { home to family life }\end{array}$ \\
\hline \multirow{2}{*}{3} & SSC & peace, own, think, war, live, family, end, children, our, understand, remember, health of the loved ones, the future \\
\cline { 2 - 4 } & SCS & $\begin{array}{l}\text { Everything will be fine, my people live peacefully, they think to end the war for their family life, so that our children } \\
\text { understand the future, remember the health of loved ones }\end{array}$ \\
\hline \multirow{2}{*}{4} & SSC & peace, own, think, life, family, understand, make, become, goal, seek, want, happy, find \\
\cline { 2 - 3 } & SCS & $\begin{array}{l}\text { Everything will be fine, my people live peacefully, think about life and family, want to become happier, find and } \\
\text { achieve goals, understand what to do }\end{array}$ \\
\hline \multirow{2}{*}{ C* $*$} & SSC & peace, own, think, life, family, understand, make, become, goal, seek, want, happy, find, war, be able, end \\
\cline { 2 - 3 } & SCS & $\begin{array}{l}\text { Everything will be fine, my people live peacefully, think about their lives and family, they want to become happy, } \\
\text { find and reach the goal, understand what they can do to end the war. }\end{array}$ \\
\hline
\end{tabular}
C* - control group.

In addition to the overall impact of hostilities under this procedure, a reaction to one of the most critical situations, the first battle, was investigated separately. For this purpose, the group №2 (directly in combat) and №3 (after returning from the war) were offered a free style to describe their emotions, experiences, thoughts, etc. after the first battle. Correlation analysis showed no correlation between these groups (at $r_{x y}=-0.06$ at $r_{\text {crit }}=0.67, p=0.05 ; r_{\text {crit }}=$ $0.80 ; p=0.01$ ). The results of semantic and sense analysis are presented in Table 4.

Table 4. Results of semantic and semantic analysis of the first battle

\begin{tabular}{|c|c|l|}
\hline \multirow{2}{*}{ Stage } & CSC & be, fear, first, all, fight, own, guys, boys, comrades \\
\cline { 2 - 3 } & CCS & The whole first battle was a fear for their guys, boys, and comrades \\
\hline \multirow{2}{*}{2} & SSC & death, which, my life, panic, danger, happen, is different, to lead, he was, it was \\
\cline { 2 - 3 } & SCS & $\begin{array}{l}\text { The whole first battle was a fear for their guys, boys, comrades. In my life, it was different. There was a danger of } \\
\text { panic that led to death }\end{array}$ \\
\hline \multirow{2}{*}{3} & SSC & fire, man, think, can, adrenaline, after, was, why, to end \\
\cline { 2 - 3 } & SCS & $\begin{array}{l}\text { The whole first battle was a fear for their guys, boys, comrades. After the fire, the adrenaline ended and a man could } \\
\text { think a day why (what) it was }\end{array}$ \\
\hline
\end{tabular}


Discussion of experimental results. On the basis of PTGQ (Table 1), it was found that the overall level of PG in the study groups №№ 2, 3, 4, 5, 6 and 7 increased by $45 \%, 34 \%, 61 \%, 37 \%, 47 \%$ and $27 \%$ compared to group №1. Interestingly, the level of PG in the average veterans who actively fought, with the advent of peaceful conditions decreased by only $4.2 \%$, the veterans of cadetspsychologists, on the contrary, increased by $6.2 \%$, and the cadets of psychologists (women) was practically the same as the fighters from the advanced. According to individual factors, even growth is observed. The greatest dynamics of growth was the factor of spiritual changes (SC) of the fighters from the advanced (grade number 2) and cadetspsychologists of women (group number 6) in comparison with the survivors (group number 1 ) respectively in 2.4 and 2,1 times. However, the dynamics of changes in individual indicators after returning from the war was ambiguous. In comparison with the progression, the attitude of veterans to society (AO) and the severity of spiritual changes (SC) significantly deteriorated. These indicators decreased in group №3, respectively, by $13 \%$ and $43 \%$, №4 - by $24 \%$ and $30 \%$, which practically equaled with other groups. Positive stands out are veterans, cadets-psychologists, who have increased the indicators of new opportunities (NO) by $65 \%$, personality forces (P) by $30 \%$, and life values (VL) by $11 \%$ compared with advanced. In comparison with the control group №7, in them the overall level of PG grew by $26 \%$, while those who did not fight only $8 \%$ (№5), and $16 \%$ (№6). A similar picture is observed on separate indicators.

On the basis of the analysis of texts (Table 2,3) at all stages of the study revealed a general positive sense orientation, which was expressed in the CCS as:"everything will be good, my people live peacefully." The SCS at the 1st stage before the start of hostilities differed significantly from everyone else and characterized only the general understanding that "only their own country to be helped" and the desire for further understanding of this situation. But at this level, PG was here the lowest. After engaging in combat, SCS has changed dramatically, becoming more concrete and expedient. The generalization of the 2nd, 3rd and 4th stages of the SCS turned out to be focused on (in priority): 1) "family life," 2) "to end the war," 3) "to become happier, to find and achieve the goal, to understand that do ", 4)" return home to your country; so that our children understand the future, remembered the health of loved ones."

However, such a seemingly logical sense picture is corrected due to the level of understanding, according to the correlation coefficient (Table 2). A complete understanding of each other was found among those who were fighting (advanced fighters, veterans and cadets). In these groups, it was shown specifically against the background of the general desire "to end the war, to be alive and healthy comrades, good life and health," as well as the fact that there are "many knowledge that must be understood, so that everything was not useless, for the sake of children, family and all people ", which is the basis for further psychological work in the direction of the PTG. Interestingly, among those who have not been fighting, with them can only be identified with women cadets psychologists $\left(r_{x y}=0,63-\right.$ $0,69)$ ). With all other understanding, conditional or absent at all $\left(\mathrm{r}_{\mathrm{xy}}=-0.05 ; 0,33\right)$.

According to this technique, texts about impressions after the first battle of fighters directly from the advanced and veterans after the return were analyzed. Their CCS was as follows: "The whole first fight was a fear for their guys, boys, comrades." SCS in the fighters from the advanced and the veterans turned out to be different and the correlation between them was not present $\left(r_{x y}=-0.06\right)$. SCS (forefront): "In my life, I've been in a different place. There was a danger of panic that led to death." SCS (peaceful conditions): "After the attack, the adrenaline ended and a man could think a day about why (what) it was." This testifies to the fact that, on the background of the general awareness of fear of others, the fighters on the advanced understanding of the battle was directed directly at understanding the threat to life (the danger of panic, death), and in peace terms, such an understanding has become deeper, aimed at understanding the essence of that what happened. The absence of correlation shows a great difference in the understanding of the war, even among the participants in the fighting. A more complete reflection begins to appear after returning.

\section{Conclusions}

1. The greater the impact of military action on the personality of the military man, the more visible the effect of the PTG, which does not decrease in peaceful conditions upon return, and those who have chosen in the future the profession of military psychologist, significantly increases.

2. Significant differences in understanding the situation before and after participating in hostilities. Before is a general understanding that Ukraine needs to be protected and the desire for further understanding of this situation, but at a low level of PG. After this is a concrete understanding of the values of life and family, the need to end the war, achieve its goal and understand what needs to be done, to become happy, to return home to your country for the sake of the future children who must remember the health of their loved ones.

3. A more complete understanding of the war veterans appears after return. The most acute critical situations, such as the first battle, are initially interpreted as "preventing death", but later as a "valuable life experience".

4. There was a misunderstanding between those who participated in hostilities and those who remained in peaceful conditions. There is a "value conflict" when the same living values (such as "life", "Ukraine", "family", "life purpose", "children", "health") are thought differently. However, the possibility of understanding is observed in women psychologists, especially motivated cadets psychologists.

\section{ЛИТЕРАТУРА}

1. Ван Дейк Т.А. Язык. Познание. Коммуникация: пер.с англ./ Сост. В.В.Петрова; Под ред. В.И.Герасимова; Вступ. ст. В.Н.Караулова и В.В. Петрова.- М.: Прогресс, 1989.-312 с.

2. Квасова О.Г. Трансформация временной перспективы личности в экстремальной ситуации: дис. ... кандидата

психологических наук: 19.00.01 / О.Г. Квасова - М., 2013. $216 \mathrm{c}$.

3. Татенко В. Методологія суб'єктно-вчинкового підходу: соціально-психологічний вимір : монографія. - К. : Міленіум, 2017. - 184 с. 
4. Ткаченко О. Психолог на війні та після... (наративні матеріали). Навчально-методичний посібник. - Київ: ЦП «КОМПРИНТ», 2017. - $176 \mathrm{c.}$

5. Tedeschi, R.G., Calhoun, L.G. (1996). The Posttraumatic Growth Inventory: Measuring the Positive Legacy of Trauma // Journal of Traumatic Stress. - V. 9. - P. 455-471.
6. Tedeshi, R.G., \& Calhoun, L.G. Posttraumatic Growth: Conceptual Foundation and Empirical Evidence. / Psychological Inquiry, 2004. Vol. 15. No. 1. P. 1-18.

7. Zipf G.K. Human Behavior and the Principle of Least Effort. Addison-Wesley Press, 1949. - C. 484-490. — 573 c.

8. Полный семантический анализ текста онлайн (seo-анализ): pecypc https://miratext.ru/seo_analiz_text

\section{REFERENCES}

1. Van Dijk T.A. Language. Cognition. Communication: Translated from English / Comp. V.V. Petrova; Ed. V. I. Gerasimova; Ingress. Art. V.N. Karaulov and V.V.Petrova .- Moscow: Progress, 1989.-312 p.

2. Kvasova O.G. Transformation of the temporal perspective of an individual in an extreme situation: dis. Candidate of Psychological Sciences: 19.00.01 / O.G. Kvasova - M., 2013. - 216 p.

3. Tatenko V. Metodology by subject- actum approacha: social psychological measurement: Monograph. - K : Millennium, 2017. - $184 \mathrm{p}$

4. Tkachenko A. Psychologist in bello et post (narratio materiae). A exercitatione-methodicam beneficium. - Kyiev: CP "KOMPRINT", 2017. - $176 \mathrm{p}$.

8. Complete semantic analysis of the text online (seo-analysis): resource https://miratext.ru/seo_analiz_text

\section{The influence of the ATO bangles action on personality of military man: post-traumatic development}

\section{A. A. Tkachenko}

Abstract. The effect of post-traumatic growth and sense dynamics before, during and after the fighting during the ATO and the return of the military man to peaceful conditions is studied. In general, the positive influence of extreme situations on the development of the veteran personality is revealed. The main problem is related to the sense contradiction in understanding the values of life on the part of those who were in peaceful conditions.

Keywords: post-traumatic growth (PTG), ATO (antiterrorist operation), bangles actions, sense dynamics, and development of personality.

\section{Влияние боевых действий АТО на личность военнослужащего: посттравматическое развитие}

\section{А. А. Ткаченко}

Аннотация. Исследуется эффект посттравматического роста и смысловая динамика до, во время и после боевых действий в ходе АТО и возвращения военнослужащего в мирные условия. Выявлено в целом позитивное влияние экстремальных ситуаций на развитие личности ветерана. Основная проблема связана со смысловым противоречием в понимании жизненных ценностей со стороны тех, кто находился в мирных условиях.

Ключевые слова: посттравматический рост (ПТР), АТО (антитеррористическая операция), боевые действия, смысловая динамика, развитие личности. 